\author{
SCHMidt Ildikó \\ Nyelvtudományi Intézet Többnyelvüségi Kutatóközpont \\ schmidtildi@yahoo.com
}

\title{
AZ ALFABETIZÁLÁS SZEREPE A MAGYAR NYELVTUDÁS KIALAKULÁSÁBAN ${ }^{1}$
}

\section{Bevezetés}

A magyarországi közoktatás kapcsán magyar egynyelvű gyermekekre szokás gondolni, de az iskolások között vannak kétnyelvü és/vagy bevándorló hátterü gyermekek is. Az utóbbi két évtizedben megnövekedett azoknak a diákoknak a száma, akiknek a nyelvi szocializációja nem magyar nyelven zajlott, ebből következően nem tudnak magyarul, amikor bekerülnek a magyar közoktatás rendszerébe. Számukra a magyar nyelv mint idegen nyelv jelenik meg a tanulmányaik kezdetén, és kezdő szintről indul el a nyelvelsajátítási folyamat. A gyermekek magyarnyelv-tudásának kiépítését az iskolák kevéssé tudják formális keretben támogatni (Schmidt 2019a), mivel a magyar mint idegen nyelv órák szervezése és órarendbe iktatása esetleges, elsősorban az iskolavezetésnek a nyelvtanulásról kialakult szemléletétől függ.

Az elmúlt néhány évben megjelent a közoktatás színterén egy másik csoport is, amely a külföldről hazatérő családokban felnövekedett gyermekekből áll. Ők általában magyar nyelven beszélő családból származnak, vagy legalább az egyik szülővel magyar nyelven beszélnek. A Magyarországra való visszaérkezésük előtt a környezetnyelv és a nevelési intézményekben használt nyelv nem a magyar volt, így a gyermekek kétnyelvűként élték mindennapjaikat. Amikor a külföldi tartózkodás után a család hazatér Magyarországra, a gyermekek nagy részének magyar oktatási és nevelési intézményekbe kell járniuk. Az életkoruktól függően vannak olyanok, akik elvándorlásuk előtt már jártak magyar óvodába, esetleg iskolába is, de sokuk közülük nem, illetve nem is Magyarországon születtek, így nincs intézményhez füződő magyar nyelvi tapasztalatuk. A nyelvtudásuk szintje roppant változatos lehet annak függvényében, hogy a befogadó ország nyelve mellett mennyire kapott hangsúlyt az életükben a származásnyelv, milyen hosszú időt töltöttek különböző nyelvi terekben, valamint milyenek az általános kognitív és affektív tulajdonságaik.

Mindkét fentebb bemutatott csoport számára fontos a magyar nyelv megfelelő szintű ismerete ahhoz, hogy sikeresen be tudjanak kapcsolódni az iskolai életbe és a tanórák menetébe. A nyelv ismeretén nem kizárólag az általános nyelvtudáselemek értendők,

1 A tanulmány az MTA NYTI Többnyelvűségi Kutatóközpont NyelvEsély szakmódszertani projektjéhez kapcsolódóan készült (SZ-007/2016, projektvezető: Bartha Csilla). 
hanem az oktatásban használatos speciális nyelvi tartalom- és nyelvi készségek is. Ez utóbbiakon belül kiemelkedő fontosságúak a literációs készségek, melyeknek megalapozása az alfabetizáláson keresztül történik.

Az alfabetizálás jelen dolgozat kontextusában a magyar nyelv hangzó- és betűrendszerének tanítását jelenti, és magába foglalja az írás-olvasás műveletiségének a fejlesztését is. A literációs készségek e területeinek a fejlesztése szükséges ahhoz, hogy a nyelvelsajátítás/ tanulás kezdeti fázisában a gyermekek képessé váljanak a szóbeli kommunikáció mellett az írott műveltségi anyaghoz való hozzáféréshez is.

A tanulmányban vázolom a literációs készségek fejlesztéséhez kapcsolódó elméleti keret jellemzőit, majd az alfabetizálás menetét, majd az első magyar alfabetizáló tananyagra hivatkozva bemutatom a fejlesztés módszertani lehetőségeit. Végül az alfabetizálás célcsoportjába tartozó egy- és kétnyelvű helyzetben lévő gyermekek magyar nyelvhez való viszonyát írom le.

\section{A literációs készségek fejlesztése és az alfabetizálás kapcsolata}

$\mathrm{Az}$ alfabetizálás során a gyermekek esetében az anyanyelvi sajátosságaiknak és a már meglévő literációs készségeiknek a figyelembevételével kell kialakítani a nyelvi fejlesztés irányát. Az írás és olvasás tanulásakor a tanuló a már meglévő szóbeli tudására támaszkodik, éppúgy, ahogyan egy első osztályba lépő kisgyermek, aki az első nyelvén magas szinten képes magát szóban kifejezni, amikor elkezd írni és olvasni tanulni. A magyar nyelvre rávetítve ez azt jelenti, hogy egy magyar anyanyelvü kisgyermek nyelvtudásbeli szintje lényegesen meghaladja a magyar nyelvet kezdő vagy akár A1-B2 szintek bármelyikén beszélő külföldi gyermekét. Nehézséget okozhat kétnyelvű gyermekeknek is az egynyelvü társaiknak kidolgozott tananyagokból való tanulás abban az esetben, amikor a kétnyelvủ gyermek domináns nyelve nem a magyar. Náluk a már kialakult literációs készségek, illetve a literációs készségekhez szükséges megelőző készségek nem a magyar nyelvhez kapcsolódnak.

A magyar mint idegen nyelv és magyar mint másodnyelv tanításába (Nádor 2018: 17) és tanulásába egyaránt szükséges beilleszteni az alfabetizálás folyamatát. Az alfabetizálás az általános nyelvtanulási folyamatba differenciáláson keresztül illeszkedik, vagy azt kiegészítve, a készségek fejlesztésének speciális jellegéből fakadóan beépülhet a magyar nyelvi órákba. A kapcsolódó óraegységek kiegészítő, moduláris anyagként jelenhetnek meg az órai munkában. Az alfabetizálás a módszertani alapelvek szintjén támaszkodik egyrészt a magyar anyanyelvi nevelés tantárgy-pedagógiájára, másrészt a magyar mint idegen nyelv sajátos, nyelvspecifikus módszertanára. A tanulók szempontjából kiindulva hangsúlyos szerepet kapnak a komplex nyelvi szintfelmérés során szerzett információk: az első nyelvi háttér, a két- és többnyelvűség jelensége, a magyar nyelvtudás szintje, az életkor és a megelőző iskolai háttér, vagyis az írott szöveghez kapcsolódó műveleti készségek szintje. Az íráson és olvasáson túl az alfabetizálás harmadik egysége a számolás, melyet a kapcsolódó nyelvi anyag és kulturális ismeretek bevezetése kísér (Schmidt 
2015a). Mivel a latin betűs íráshoz, azon belül a magyar nyelvhez kapcsolódó betűkön kívül a számjegyeket, a számokra utaló kézjeleket és a műveleti jeleket is magába foglalja az alfabetizálás, a számok kézzel történő mutatása erősen specifikus magyar jegyeket mutat. A mindennapi kommunikációban elengedhetetlenül fontos ezeknek az ismerete, különösen abban a fázisban, amikor a beszédértés még kevésbé pontos, és a kézjeleken keresztül történő kommunikáció előtérbe kerül.

A literációs készségekhez kapcsolódó módszertani háttér kialakításában alapvető fontosságú a magyar anyanyelvi nevelési programokra való támaszkodás. A jelenlegi általános gyakorlat szerint az iskolákba belépő gyermekek a magyar anyanyelvi oktatásban használatos tananyagokból tanulnak írni és olvasni. Az ebből történő alfabetizálás sikeressége kérdéses, minthogy ezeket a tankönyvcsomagokat a magyarul első nyelvi szinten beszélő kisiskolásokra szabják. Ez elsősorban a szókészlet és a nyelvi formák tekintetében jelent akadályt. A különböző szemléletű programok közül a tanítási tapasztalatok alapján a Meixner-módszer bizonyult a leghatékonyabbnak az alfabetizálás szempontjából. A diszlexia prevenciós programokban résztvevő tanulók és az átlagos nevelési igényü magyar anyanyelvű tanulók mellett a kétnyelvű tanulók és a magyar mint idegen nyelvet tanulók számára egyaránt ez a módszer a legmegfelelőbb, mivel figyelembe veszi a hangképzés és betűformálás során fellépő interferenciajelenségeket (Meixner 1993). A módszertani alapelveket tekintve a betűsorrend, vagyis a betűk egymás utáni sorrendje követi a hangképzés sajátosságait, amely elkerüli a hangok és betűk hasonló mivoltából fakadó interferenciajelenségeket. Ez a hangok esetében az egymáshoz közel eső hangképzési mozzanatokat mutató hangok közötti összemosódást jelenti, a betűknél pedig a formai jegyek közötti vizuális hasonlóságon alapuló felcserélést.

Az eltérő vizuális kultúrában felnövekvő gyerekek esetében a literációs készségek kialakulásakor kitüntetett szerep jut annak a ténynek, hogy az első nyelvüket jobbról balra haladó írásirány jellemzi, szemben a magyar nyelv balról jobbra tartó írásmódjával. Függetlenül attól, hogy a gyermekek adott esetben még nem tanultak írni-olvasni, a vizuális környezet, a megszokott képi valóság sajátosságai jelentősen befolyásolják a térbeli percepciót. Az így leírt vizuális tapasztalatokkal rendelkező gyermekek esetében fokozott hangsúlyt kell fektetni az írás-olvasást megelőző előkészítő fázisban a szenzomotoros képességek vizsgálatára és fejlesztésére (Gyarmathy 2007: 90-92). Kiemelten fontos terület a téri orientáció, a sorba rendezés: téri és időbeli sorozatok létrehozása, a szemmozgás és a finommotorikus mozgások iránya.

A literációs készségek alapjául szolgáló alfabetizálás során további nehézséget jelenthet a folyóírás tanulása, melyet az írni tanuló magyar első nyelvű gyermekeknek az írás műveletiségén túl a finommotorikus fejlesztésre összpontosítva írásképként tanítanak. A folyóírás tanítása megfelelő az általános iskola első két osztályába beíratott $6-8$ éves egynyelvű, vagyis magyarul még nem tudó és kétnyelvű, magyarul is tudó kisiskolások számára, mivel ők a domináns nyelvükön az életkorukból fakadóan még nem jutottak el a készségszintű írástevékenységhez. Az előzőekben leírt nyelvi háttérrel rendelkező 
9 és 16 éves kor közötti tanulók esetében gyakran előfordul, hogy az intézményvezető döntése alapján alacsonyabb osztályba sorolódnak (Schmidt 2015b). Ezért gyakori, hogy tíz év körüli gyermekek első-második osztályban kezdik el az iskolát, annak ellenére, hogy az első nyelvükön vagy kétnyelvű helyzetben a domináns nyelvükön már tudnak írni-olvasni, még ha nem is készségszinten. Az ilyen esetekben elengedhetö lenne a folyóírás hosszadalmas folyamatának a beillesztése, melyet az is indokol, hogy a diákoknak a magyar nyelvet kell a lehetö leggyorsabban olyan szinten megtanulni, hogy képesek legyenek a magyar nyelven folyó óravezetés megértésére és az órákba való bekapcsolódásra. Az idősebb tanulókra fokozottan igaz a nyelvtanulás miatti leterheltség, és az ő esetükben még inkább valószínűsíthető, hogy az első nyelvükön képesek már készségszinten írni-olvasni, így nincs szükségük a folyóirás megtanulására. Ilyen esetekben a folyóírást felváltja a nyomtatott írásképhez közelebb álló technika, a funkcionális íráskép (Schmidt 2013). A literációs készségek fejlesztésekor az írás tanulásával párhuzamosan belép az olvasástanulás is, melyet megkönnyít, ha a tanuló a nyomtatott írásképhez közelebb álló írásképet tanul meg leírni és elolvasni.

A literációs készségek kialakításának alapja a beszélt nyelvből kiinduló fonémagraféma differenciálás. Ez egybeesik az alfabetizálás módszertani alapelveivel, amelynek értelmében a fonéma-graféma differenciálás terén öt nagy fejlesztési terület határozható meg: a beszédmotorika, az auditív differenciálás, az auditív-vizuális intermodalitás, a beszédmotorika, a vizuális differenciálás és a vizuomotoros koordináció (Gósy 2002; Porkolábné 2002, 2005, Vas 2002; Zsoldos 2002). Az egyes területek a következőképpen definiálhatók. A beszédmotorika működése során a hallott hangok és szavak pontos észlelése és megismétlése történik, amely lehetővé teszi a beszédértés és a beszédprodukció sikeres működését. Az auditív differenciálás, vagyis a hangok és a hangsorok megkülönböztetése az azonos, illetve hasonló hangzású hangok, szótagok, szavak hallás utáni megkülönböztetésének, a finom hangzásbeli különbségek észlelésének a képessége (Schmidt 2018b: 37). Az auditív-vizuális intermodalitás a szavak és a hangok felidézése képekkel és betűkkel. Ezen a területen lényeges, hogy a rövid távú emlékezet kiemelkedően fontos szerephez jut a tanulási folyamat során, hiszen ezen keresztül válik lehetővé a hangok betűkhöz, illetve a szavak képekhez való kapcsolása. A felidézési folyamat eredményeképpen a rövid távú emlékezetben tárolt hang, hangsor vagy szó kiválasztása a betűk és képek közül elérhetővé válik (Schmidt 2018b: 50). A vizuális differenciálás a betűk és számok írott alakjának a megkülönböztetését jelenti (Schmidt 2018b: 44). A látáson keresztül felvett információk pontos percepciója és feldolgozása adja az azonosság és a különbség észlelését a betűk és a számok összehasonlítása során. A vizuomotoros koordináció, vagyis a szem és a kéz összehangolt munkája képezi az írástechnika alapját (Schmidt 2018b: 39). A folyamat a pontos vonalvezetésből indul ki, ami a látás által pontosan irányított és kontrollált mozgás kivitelezésében nyilvánul meg.

A graféma-fonéma differenciáláskor a fentebb leírt fejlesztési területekből kiindulva a betűk közötti kiejtésbeli és vizuális különbségek szerepe hangsúlyossá válik, így több 
szempontból is figyelembe kell venni. Egyrészt a zöngés-zöngétlen párok $(v-f, b-p, g-k$, $d-t)$ gyakoroltatását illetően, mivel ezeknek az oppozícióknak a készségszintű elsajátításához hosszú idő kell, amelyet jelentősen befolyásol a diák anyanyelve és előzetes nyelvi tapasztalatai (Schmidt 2018b: 94). Másrészt a differenciálás különösen nehéz a hangképzés szempontjából egymáshoz közel eső hangok esetében $(l-r, c s-t y, g y-d z s)$, ami föként a beszéd akcentualizáltságának mértékét határozza meg (Schmidt 2018b: 82). A beszédprodukció szintjén lényeges, hogy a beszélő elérje a hallgatóság számára még jól feldolgozható akcentusminőséget, a Kenworthy által kényelmes jólérthetöséggel leírt szóbeli performanciát (Bárdos 2002: 106). Az írás terén belép az íráskép hasonlósága miatti betütévesztés ( $b-d$, $b-p, d-p, p-q, m-n)$, ami az olvasás terén fokozottan érvényesül. Az olvasás során a betütévesztés elsődlegesen értelemzavaró jelenség, másodlagosan pedig erőteljesen lelassítja az olvasást, olyannyira, hogy a betűzés lassúsága miatt a már elolvasott és megértett egységeket újra kell olvasni, mert az olvasó időközben elfelejti a korábbi elemeket. Írás esetében az általában eleve nehezen olvasható szöveget roncsolja a nem megfelelő betủválasztás, ami demotiválja az olvasót a túlzott figyelmet igénylő művelet során.

Némileg távolabb esik az eddigi gondolatoktól a nagybetűk használata és tanítása. Vannak bizonyos betűk, amelyekkel gyakorlatilag nem kezdődnek magyarul szavak, így nagybetűs helyzetbe, mondat elejére nem kerülhetnek. Ezeknek a betűknek a nagybetűs alakját nem feltétlen szükséges beépíteni a tananyagba $(d z, d z s)$. Azonban vannak olyan betűk, amelyekkel magyarul ugyan nem kezdődnek szavak, viszont más kultúrákban a személy- és a földrajzi nevek írásánál gyakori a megjelenésük. Bizonyos nyelvekről latin betűs ábécére átírt nevek esetében használatos a $Q, Y$ és $X$ betű, így ezen nagybetűknek a tanítása mindenképpen szükséges (Schmidt 2018b: 106).

\section{A magyar nyelvre történő alfabetizálás jelentősége egynyelvű tanulók esetében}

A magyar nyelvet változatos nyelvi háttérrel rendelkező gyermekek tanulják. Ebben a részben olyan tanulók alfabetizáláshoz való viszonyáról lesz szó, akik egynyelvűek és a magyart idegen nyelvként kezdik tanulni. Esetükben többnyire nyelvelsajátítási folyamatról beszélhetünk, mivel általában a magyar nyelvvel való találkozásuk közoktatási intézményekbe bekapcsolódva indul. Korábbi tapasztalataik, tanulmányaik nincsenek, amelyek a magyar nyelvet érintenék, így ez jellemzően az első iskolában eltöltött nappal kezdődik. A magyar közoktatási rendszerbe érkező gyermekek nem kapnak előzetes nyelvi felkészítést, és leszámítva a magyar mint idegen nyelv órákat, saját készségeikre támaszkodva kell elsajátítaniuk az oktatás nyelvét. A magyar mint idegen nyelv órák szervezése az iskolák hatáskörébe tartozik, és többnyire az iskolavezetéstől függ, hogy egyáltalán szerveznek-e ilyen foglalkozásokat. Amennyiben a tanulók lehetőséget kapnak nyelvi felzárkóztatáson való részvételre, kérdéses, hogy az adott pedagógus mennyire ért a nyelvtanításhoz, illetve mennyire érzi magáénak a feladatot. Kutatási eredmények 
bizonyítják, hogy a nyelvi fejlesztésre szükség van, melynek tartalmi vonatkozásai is kirajzolódtak (Schmidt 2017, 2019a). A fejlesztés megkezdése előtt szükséges felmérni a tanuló szociális és nyelvi készségeit. A készségek feltérképezéséhez jól használható a komplex nyelvi szintfelmérés, amely tágan értelmezi és járja körül a tanuló általános és nyelvi fejlettségét, figyelembe véve a családi háttérből fakadó sajátosságokat is. A komplex nyelvi szintfelmérés használatának eredményeiből látszik, hogy az iskolába lépő gyermekek esetében gyakorlatilag minden esetben szükséges az alfabetizálást beépíteni az iskolába lépés kezdeti szakaszában a literációs készségek kiépítéséhez, mivel az alfabetizálás segítséget nyújt mind a magyar nyelv hangzó- és betűkészletének megtanulásához, mind a literációs készségekhez kapcsolódó műveleti tudás megszilárdításához és magyar nyelvre való alkalmazásához (Schmidt 2014).

Az alsó és a felső tagozatra beiratkozó gyermekekről egyaránt elmondható, hogy a nyelvi integráció több színtéren valósul meg egyszerre, az iskolán kívül is számos élmény és tapasztalat éri a gyermekeket. A nyelvtanulóknak még a folyamatos nyelvi kitettség mellett is évekig tart, míg a legalapvetőbb kommunikációs helyzeteken keresztül eljutnak a mindennapi élet változatos nyelvhasználatáig. E mellett az elsajátítási folyamat mellett a gyermekeknek az iskolában a tanórákon használt szókészletet és a nyelvi formák széles skáláját kell megtanulniuk és használniuk ahhoz, hogy sikeresen tudják befejezni az adott évfolyamot, és megalapozott tudással felvértezve kezdjék el a következő iskolaévet. Az integráció jósolt idejének kiemelkedő szerepe van, mivel az első nyelvi beszélőt megközelítő szintű nyelvi integráció eléréséhez Baker szerint összesen 5-8 évre van szükség (Baker 2011: 12). Ezen belül a mindennapi nyelvhasználat magas szintű alkalmazása 2-3 év után várható, míg az ezzel párhuzamosan zajló oktatási nyelv elsajátítása akár nyolc évig is eltarthat. Az időbeli folyamat hosszúsága miatt mindenképpen alapos fejlesztési tervre van szükség annak érdekében, hogy az alfabetizálás és az írásbeli nyelvhasználathoz való hozzáférés a lehető leggyorsabban történjen meg. Különösképpen akkor, ha egy tanuló nem alsó tagozatos gyermekként kerül szembe a nyelvi integráció kihívásaival, hanem a felső tagozatnak megfelelő életkorban (Schmidt 2017).

Az alsó tagozatos gyermekeknek az életkorukból fakadóan hosszabb idő áll rendelkezésükre, így látszólag könnyen beilleszkednek magyar első nyelvű osztálytársaik közé, és várhatóan gyorsabban történik a nyelvelsajátítás. Kérdéses azonban, hogy az első nyelven milyen szintre jutott el a tanuló a literációs készségek kiépülésében: vajon elegendő időt tudott-e eltölteni a származási ország iskolarendszerében az írás és olvasás műveleti tudásának elsajátításához és készségszintủ megszilárdításához. Általánosságban elmondható, hogy az alsó tagozatos gyermekek esetében az első nyelven megszerzett literációhoz kapcsolódó műveleti tudás magyar nyelvre történő transzferálása nehézségekbe ütközhet. További akadály lehet, hogy a tanuló számára idegen nyelven kell megtörténnie a már meglévő, ámde más nyelvhez kapcsolódó procedurális tudás megszilárdításának, párhuzamosan az új nyelv elsajátításával. Az említett két folyamatot - a műveleti tudás transzferálását és megszilárdítását - hátráltathatja, hogy bizonyos nyelvekkel szemben 
a magyar nyelvnek az írásiránya ellentétes. Ebben az esetben a már akár automatizálódott iránytartás az olvasás és az írás terén is zavart okozhat, ezért hosszabb idő szükséges az új irány a megszokásához (Schmidt 2018a). Az átállás ideje alatt a biztonságos beidegződés hatékonyan segíthető fejlesztő pedagógiai módszerek alkalmazásával.

A felső tagozatra érkező egynyelvủ tanulók éppúgy, mint az alsó tagozatosak, nem tudnak magyarul, így a nyelvelsajátítás az iskolába lépéssel indul. Az életkorukból fakadóan ez a folyamat lassabb, és az eredményessége nehezebben jósolható meg, mint kisebb gyermekeknél (Schmidt 2019a). A tanulóknál számítani lehet arra, hogy a magyar nyelvű osztályba érkezésük előtt jártak már iskolába, így kialakult, biztos literációs készségháttérrel rendelkeznek az első nyelvükön (a szélsőséges példáktól eltekintve). A komplex nyelvi szintfelmérések eredményei alapján látható, hogy az iskolában eltöltött évekből következtethetünk arra, hogy a tanulók készségszinten állnak-e az írás- és az olvasás terén. Valószínűleg nem okoz majd nehézséget számukra a már meglévő műveleti tudásuk alkalmazása, és a magyar nyelvre való transzferálása. Emellett a magyar hangzórendszer és az ábécé megismerése elengedhetetlenül fontos a nyelvtudás hatékony és gyors megszerzéséhez. Különösképpen fontos a sebesség, mert az iskolába lépéskor a nyelvhez kapcsolódó órákkal párhuzamosan a szaktárgyi órákon is részt kell venniük. A tankönyvszövegek és az órán elhangzó szóbeli megnyilatkozások a lexikai terheltség és a nyelvi formák eltérő volta miatt nagymértékben eltérnek a mindennapi életben használtaktól, így ennek elsajátítása roppant nagy erőfeszítést igényel a tanulóktól.

\section{A magyar nyelvre történő alfabetizálás jelentősége kétnyelvü tanulók körében}

Kétnyelvű gyermekeknél lényegesen egyszerủbb a magyar nyelvủ literáció kiépítése, mivel a beszélt nyelvből kiindulva az alfabetizálás során a már meglévő nyelvtudásra alapozva történhet ez a folyamat. Nem nehezedik rá a párhuzamosan végbemenő nyelvelsajátítás, hanem a már jól működő nyelvi rendszerre simul rá, még akkor is, ha akcentualizált a beszéd, vagy a lexikai elemek főként a hétköznapi beszédhelyzetekhez kapcsolódnak, vagy a nyelvi formák használata ingadozó, akár köztesnyelvre emlékeztető is.

A kétnyelvű tanulóknál a magyar nyelv mint származásnyelv vagy mint környezetnyelv jelenik meg a tanulás során (Nádor 2018: 16). Környezetnyelv esetén az otthon használt nyelv jellemzően nem a magyar nyelv, hanem a szülők által beszélt származásnyelv, vagy az egyik szülő anyanyelve. Amennyiben a gyermek az iskolába lépéstől kezdődően a magyar közoktatásban tanul, akkor probléma nélkül tanulhat meg magyarul írni és olvasni. Abban az esetben viszont, ha a tanuló Magyarországon él, de nemzetközi iskolában folytatja tanulmányait, nem feltétlen épülnek ki a literációs készségei magyar nyelven, amelyből következően kialakításuk során szükségessé válhat az alfabetizálás beépítése. A fonéma-graféma kapcsolatok kiépítésekor a kétnyelvű gyermekeknél nem pusztán a magyar nyelvre jellemző intralingvális megfeleltetéseket 
kell differenciálni, hanem a két nyelv között meglévő fonéma-graféma kapcsolódásokat is. Így a nyelvek közötti, interlingvális kapcsolódási pontokat is érdemes beemelni a fejlesztésbe. Ezzel a megközelítéssel elérhető, hogy a gyermek az írás és olvasás folyamata során a felmerülő hangok és betűk közül az adott nyelvnek megfelelő formát tudja választani. Az egyes jelek bár egy rendszerben jelennek meg, de a két nyelv rendszeréhez igazodóan válnak választhatóvá, amivel elkerülhetőek a nem kívánt transzferjelenségek, úgy az olvasás során a kiejtésben manifesztálódva, mint íráskor a megfelelő betűsor lejegyzésekor.

Sok gyermek él külföldön a családjával, ahol a domináns nyelv jellemzően nem a magyar nyelv, hanem az élethelyükön beszélt környezetnyelv. Ebben az esetben beszélünk származásnyelvi kétnyelvűségről a magyar nyelv viszonylatában. A gyermek ilyen helyzetben nem találkozik a magyar nyelvvel az oktatásban, többnyire hétvégi/ vasárnapi iskolákban tanulja a magyar nyelvet célzó literációt. A középpontban rendszerint a hagyományőrzés és a magyarországi mindennapok kontextusának a megteremtése áll. E cél mellett elengedhetetlenül fontos, hogy a tevékenységek között megjelenjenek az anyanyelvi nevelés szempontjai is. Ezek a gyermekek változó szinten beszélnek magyarul, sokuk közülük veszít a nyelvtudásából, amint az új ország nyelvét elsajátítja, és domináns helyzetbe kerül a gyermek anyanyelvével szemben. Ez egy természetes szociolingvisztikai folyamat: a kommunikációban többet használt nyelv egyszerűen átveszi a korábban domináns nyelv szerepét. Ez azonban nem jelenti azt, hogy a gyermek elveszíti az anyanyelvét, vagyis nyelvvesztés áll be (Kiss 2002: 223), csak egy időre a magyar nyelv a háttérbe szorul, nyelvgyengülés történik. (Schmidt 2019b). Lényeges viszont, hogy a nyelvgyengülés folyamata közben megtörténjen a nyelvfenntartás, amely meggátolja a - szakirodalomban használt kifejezéssel élve - nyelvvesztést (Gal 1992). A nyelvfenntartáshoz elengedhetetlenül fontos a literációs készségek minél magasabb szintủ kiépítése, amelyhez viszont szükséges az alfabetizálás beépítése a nyelvi fejlesztésbe. Ez a folyamat hasonló a fentebb leírt nemzetközi iskolákban tanuló diákok nyelvi fejlesztéséhez, amikor a nem-domináns nyelvre irányulnak a tevékenységek. A nyelvfenntartás gondolatát az is erősen motiválja, hogy a Magyarországtól távol élő családok életében beállhat olyan változás, amikor visszatérnek az anyaországba. Ennek bekövetkeztekor a gyermekeknek készen kell állniuk a magyar oktatási rendszerbe való bekapcsolódásra, illetve visszakapcsolódásra. Felnőttekkel végzett retrospektív életútinterjúk bizonyítják (Schmidt 2019a), hogy a magyar közoktatásból kilépés, majd visszatérés folyamata érzelmileg jelentősen terhelt élményként jelenik meg az élettörténetükben, némelyeknél traumatizáló hatású volt. A leírt élmények középpontjában a nyelvi idegenség érzése áll, mind az elvándorláskor a másik (idegen) nyelvi környezetbe való belépéskor, majd a hazatéréskor, a magyar nyelvi környezetbe való visszakapcsolódáskor. Ezt a kutatási eredményt felhasználva a lehető legtöbb támogatást kell adni azoknak a gyermekeknek, akikkel bármikor megtörténhet ennek a folyamatnak az átélése. 


\section{5. Összegzés}

A literációs készségek kiépítésének alapja a megfelelő szintű alfabetizáltság, legyen szó bármely nyelvről is. Az adott nyelv graféma-fonéma megfeleltési szabályainak készségszintü ismerete vezet el az írás-olvasás, vagyis a szövegalkotás és szövegértés automatizált műveleti szintű műküdéséhez. A magyar nyelvủ literáció kiépítése különböző nyelvi háttérrel rendelkező gyermekek esetében eltérő szintű magyar nyelvtudás megléte mellett kezdődik. A tanulmányban láttuk, miként zajlik az iskolába lépés pillanatától a nyelvelsajátítás, a szaknyelvi szókincs és a kapcsolódó nyelvi formák kialakulása egynyelvű és két- vagy többnyelvű tanulók esetében. Az is megfogalmazódott, hogy a magyar oktatási rendszerbe becsatlakozó, vagy oda visszatérő valamennyi tanuló számára szükséges a literációs készségek kialakulásának kezdeti fázisára irányuló fejlesztést beiktatni. Ennek alapja az alfabetizálás, amelynek igazodnia kell a nyelvtudás szintjéhez, és a tanuló beszélt nyelvi produkciójára kell épülnie.

\section{Irodalom}

Baker, Colin 2011. Foundation of bilingual education and bilingualism. Clevedon: Multilingual Matters.

Bárdos Jenő 2002. Az idegen nyelvi mérés és értékelés elmélete és gyakorlata. Budapest: Nemzeti Tankönyvkiadó.

Gal, Susan 1992. Mi a nyelvcsere és hogyan történik? In: Kontra Miklós (szerk.): Társadalmi és területi változatok a magyar nyelvben. Budapest: MTA Nyelvtudományi Intézete. 47-59.

Gósy Mária 2002. A beszédészlelés és a beszédmegértés folyamatának zavarai. (A beszédfeldolgozás hibás müködése. A beszédfeldolgozási zavar megjelenési formái. A beszédfeldolgozás zavarának okai. A beszédfeldolgozás zavarainak osztályozása) In: Martonné Tamás Márta (szerk.): Fejlesztő pedagógia. Budapest: ELTE Eötvös Kiadó. 121-126.

Gyarmathy Éva 2007. Diszlexia. A speciális tanitási zavar. Budapest: Lélekben Otthon Kiadó.

Kiss Jenő 2002. Társadalom és nyelvhasználat. Szociolingvisztikai alapfogalmak. Budapest: Nemzeti Tankönyvkiadó.

Meixner Ildikó 1993. Játékház - Betütanitás irásfüzet I-II. az általános iskolák I. osztálya számára. Budapest: Nemzeti Tankönyvkiadó.

Nádor Orsolya 2018. Tanitott (anya)nyelvünk. Magyarnyelv-tanári segédkönyvek. Budapest: Károli Gáspár Református Egyetem - L’Harmattan Kiadó.

Porkolábné dr. Balogh Katalin 2002. A korai prevenciós fejlesztés. In: Martonné Tamás Márta (szerk.): Fejlesztö pedagógia. Budapest: ELTE Eötvös Kiadó. 11-31.

Porkolábné Balogh Katalin 2005. A tanulási képességet meghatározó pszichikus funkciók fejlődése, a tanulási nehézségek korai felismerésének lehetőségei, a fejlesztés perspektívái. In: Balogh László - Tóth László (szerk.): Fejezetek a pedagógiai pszichológia köréböl. Budapest: Neumann Kht. 
Schmidt Ildikó 2013. Alfabetizálás a magyar mint idegen nyelvi órákon. Hungarológiai Évkönyv 14: 88-96.

Schmidt Ildikó 2014. A magyar közoktatásba belépő migráns tanulók komplex nyelvi szintfelmérése. THL2 1-2: 22-33.

Schmidt Ildikó 2015a. Az interkulturális bevezető kurzusok szerepe a társadalmi integráció elősegítésében. Alkalmazott Nyelvészeti Közlemények 10: 213-218.

Schmidt Ildikó 2015b. Migráns gyerekek beiskolázásának gyakorlata csoportos esettanulmányon keresztül. THL2 1-2: 106-114.

Schmidt Ildikó 2017. Bevándorló tanulók iskolai integrációja Magyarországon Esettanulmány. In: Maróti Orolya - Nádor Orsolya - Bándli Judit (szerk.): 225-6560 év a magyar mint idegen nyelv oktatásában. Budapest: Balassi Intézet. 297-306.

Schmidt Ildikó 2018a. Az írás és az olvasás tanításának lehetőségei a magyar iskolákban az eltérő vizuális háttérrel rendelkező gyermekek számára: az írásirány különbözősége és a szenzomotoros képességek fejlesztése. THL2 1-2: 88-98.

Schmidt Ildikó 2018b. Betürend. MagyarOK alfabetizáló munkafüzet. Pécs: Pécsi Tudományegyetem.

Schmidt Ildikó 2019a. Migráns tanulók nyelvi integrációja a magyar közoktatásban. (Esettanulmány: egy afgán testvéspár egy budapesti iskolában) Doktori disszertáció. Kézirat.

Schmidt Ildikó 2019b. Bevándorló gyerekek közoktatásbeli integrációja a befogadó iskola szempontjából. In: Dégi Zsuzsanna - Tankó Enikő - Tódor Erika-Mária (szerk.): Nyelvi tájkép, nyelvi sokszinüség. Sepsiszentgyörgy, Románia: Sapientia EMTE Csíkszeredai Karának Humántudományok Tanszéke. 151-163.

Vas Erika 2002. Az alapozó mozgásterápia egy eset tükrében. In: Martonné Tamás Márta (szerk.): Fejlesztö pedagógia. Budapest: ELTE Eötvös Kiadó. 67-71.

Zsoldos Márta 2002. Kognitív fejlesztőterápia a tanulási zavarok kezelésében. Brigitte Sindelar kognitív fejlesztő programja. In: Martonné Tamás Márta (szerk.): Fejlesztő pedagógia. Budapest: ELTE Eötvös Kiadó. 72-87. 